\title{
EFEKTIFITAS EKSTRAK DAUN PEPAYA DALAM MENUNJANG KEBERHASILAN PENETASAN TELUR IKAN BANDENG (Chanos chanos Forskall)
}

\section{(Effectivity of the Papaya Leaf's Extract in Supporting Hatching Succes of the Milk Fish (Chanos chanos Forskall))}

${ }^{1}$ Teuku Fadlon Haser*, ${ }^{1}$ Suri Purnama Febri, ${ }^{2}$ Muh. Saleh Nurdin

${ }^{1}$ Program Studi Budidaya Perairan Fakultas Pertanian Universitas Samudra, Langsa Aceh

(email: teukufadlon@unsam.ac.id) (email: suripurnama@unsam.ac.id)

${ }^{2}$ Program Studi Akuakultur Fakultas Peternakan dan Perikanan Universitas Tadulako, Palu

(email:salehnurdin@untad.ac.id)

\begin{abstract}
The milk fish is an economically important species with high market demand. The availability of of milk fish fries has been becoming the inbitor in supporting milk fish production. Herbal ingredients such as papaya leaf's extract can be an alternative to improve the success rate of hatchings and reduce fry abnormalities. The research aimed to examine the effectivity of papaya leaf's extract in increasing hatching rate, and reducing the rate of abnormalities in milkfish fries. The treatment consists of six level concentration of papaya leaf's extract which includes 2, 4, 6, 10, 20 and $25 \mathrm{ml}$. The research resulted in the highest success rate and the lowest abnormalities occur to the tratment with $4 \mathrm{ml}$ papaya leaf's extract $(89,94 \pm 1,61 \%$ dan $6,54 \pm 2,47 \%)$. Therefore, papaya leaf extraction can significantly help to improve the success rate and minimize milk fish fries abnormality.

Keyword: milkfish, papaya leaf's extract, hatching rates, abnormalities.
\end{abstract}

\begin{abstract}
ABSTRAK
Ikan bandeng merupakan salah satu jenis ikan ekonomis penting dengan permintaan pasar yang tinggi. Kegiatan budidaya ikan bandeng masih terkendala oleh ketersediaan nener dari hasil perbenihan. Pemanfaatan bahan herbal seperti ekstrak daun pepaya menjadi salah satu alternatif untuk meningkatkan keberhasilan penetasan dan mengurangi abnormalitas benih. Penelitian bertujuan mengetahui efektifitas ekstrak daun pepaya dalam meningkatkan daya tetas dan mengurangi abnormalitas benih. Perlakuan yang diujikan adalah konsentrasi ekstrak 2, 4, 6, 10, 20, dan $25 \mathrm{ml}$. Penelitian menunjukkan persentase daya tetas telur tertinggi dan abnormalitas terendah terdapat pada perlakuan konsentrasi $4 \mathrm{ml}(89,94 \pm 1,61 \%$ dan $6,54 \pm 2,47 \%)$. Ekstraksi daun pepaya secara signifikan efektif dalam meningkatkan keberhasilan penetasan telur dan menurunkan abnormalitas benih ikan bandeng.

Keyword: ikan bandeng, ekstrak daun pepaya, daya tetas, dan abnormalitas.
\end{abstract}

PENDAHULUAN

Usaha perikanan budidaya saat ini mampu memberikan kontribusi yang cukup besar terhadap pendapatan masyarakat, penyediaan lapangan kerja, dan meningkatkan perolehan devisa negara 
(Malik, 2010; Ratnawati et al., 2010). Ikan bandeng (Chanos chanos) merupakan salah satu jenis ikan ekonomis penting karena banyak dikonsumsi oleh masyarakat Asia Tenggara khususnya di Indonesia (Jaspe dan Caipang, 2011; Tutas et al., 2013; Budiasti et al., 2015; Virgula et al., 2017; Sembiring et al., 2017; Aslamyah et al., 2018) dan menjadi salah satu sumber protein hewani untuk masyarakat karena mempunyai rasa daging yang enak dengan harga terjangkau (Andriyanto, 2013; Kusumawati et al., 2017) dengan kandungan gizi seperti asam lemak omega-3 berupa EPA, ERA, dan DHA.

Budidaya ikan bandeng di Indonesia sebagian besar masih menerapkan teknologi tradisional dan sebagian kecilnya lagi telah menerapkan teknologi semi intensif (Zamroni et al., 2015; Martuti et al., 2016). Ikan bandeng saat ini telah menjadi komoditas budidaya di negara-negara Asean seperti Philipina, Taiwan, dan China (Hikmayani dan Putri, 2014; Tumilba dan Yarime, 2015; Apines-Amar et al., 2015; Langaoen et al., 2018).

Masalah yang dihadapi saat ini oleh pembudidaya ikan bandeng ialah tidak terpenuhinya kebutuhan benih (Hikmayani dan Putri, 2014), akibat dari rendahnya daya tetas telur, serangan mikroba, dan penyebab penyakit lainnya yang menjadikan telur menjadi busuk (Priyono et al., 2011; Saptiani et al., 2016). Salah satu alternatif yang ditawarkan untuk penyelesaian masalah di atas yaitu penggunaan bahan aktif yang dicampurkan kedalam pakan.

Salah satu tanaman yang sering digunakan sebagai bahan aktif dalam percepatan proses daya tetas adalah daun pepaya. Pemanfaatan daun pepaya untuk kultivan (organisme budidaya) sering dilakukan melalui pakan dengan cara mencampurkannya ke dalam pakan kultivan sebagai salah satu cara dari peralihan pakan dari pakan alami ke pakan buatan (Mardjono et al., 2013). Pepaya diketahui memiliki kandungan enzim papain, dan senyawa antimikroba, sehingga dapat dijadikan imunostimulan ((Haryani et al., 2012; Amri dan Mamboya, 2012; Nwofia et al., 2012; Nwofia dan Ojimelukwe, 2012; Pandey et al., 2016; Monica et al., 2017) yang berperan dalam meningkatkan imunitas pada ikan baik stadia larva ataupun indukan. Kandungan senyawa enzim papain dan senyawa anti mikroba yang terdapat dalam pepaya tersebut memiliki potensi untuk memelihara kesehatan telur, oleh karena itu penelitian ini dilakukan untuk mengetahui efektifitas berbagai konsentrasi ekstrak yang diperoleh dari daun pepaya dalam menunjang keberhasilan penetasan dan penekanan terhadap abnormalitas larva.

\section{BAHAN DAN METODE}

Penelitian dilaksanakan pada bulan April-Juni 2018. Penelitian ini menggunakan rancangan acak lengkap (RAL), terdiri dari enam perlakuan masing-masing tiga ulangan sehingga diperoleh 18 satuan percobaan. Telur ikan bandeng (Chanos chanos) diperoleh dari hasil pemijahan di Balai Perikanan Budidaya Air Payau (BPBAP) Aceh Besar. Jumlah telur yang digunakan dalam penelitian ini adalah 100 butir telur/wadah.

Daun pepaya dicuci dan dibuang pertulangan kerasnya, selanjutnya dipotong kecil dan dikeringbekukan dalam freeze dryer pada suhu $-108^{\circ} \mathrm{C}$ (Kusmiati, 2012). Pepaya yang telah dikeringkan kemudian dihaluskan dan serbuk di tambahkan dengan $200 \mathrm{ml}$ etanol/10 gram serbuk daun pepaya. Selanjutnya ekstrak daun pepaya yang telah dicampur etanol disaring dengan menggunakan whatman paper no. 1 yang ditampung dalam baskom untuk dipekatkan dengan menggunakan rotari evaporator pada 
suhu $45^{\circ} \mathrm{C}$, hingga diperoleh hasil ekstraksi yang siap pakai. Perendaman telur dilakukan dalam wadah berisi air volume 5 L. Ekstrak daun pepaya yang telah diencerkan ditambahkan ke dalam wadah perlakuan sesuai konsentrasi, yaitu 2, 4, 6, 10, 20, dan $25 \mathrm{ml}$. Penentuan konsentrasi merujuk pada penelitian Azwar (2017), yang menggunakan konsentrasi 10 dan $20 \mathrm{ml}$ namun belum menemukan konsentrasi yang optimal, sehingga digunakan konsentrasi dengan kisaran yang lebih luas. Perendaman dilakukan sampai telur menetas, selama proses penetasan dalam wadah diberikan aerasi guna asupan oksigen terlarut dalam proses pemecahan chorion (Walidin, 2017).

\section{Persentase Daya Tetas}

Data yang diperlukan untuk mengetahui persentase daya tetas telur adalah banyaknya telur yang menetas pada masing-masing perlakuan. Persentase daya tetas telur dihitung dengan menggunakan rumus yang digunakan oleh Andriyanto et al., (2013):

$$
D T=\frac{(a+b)}{(a+b+c)} \times 100
$$

Keterangan : DT : Daya Tetas Telur (\%); a : Jumlah telur yang menetas normal; $b$ :
Jumlah telur yang menetas tidak normal; dan c : Jumlah telur yang tidak menetas.

\section{Abnormalitas Larva}

Pengamatan abnormalitas dalam penelitian ini meliputi bentuk kepala, bentuk tubuh dan bentuk ekor. Untuk mengetahui besarnya abnormalitas pada larva ikan bandeng digunakan rumus seperti yang dikemukakan oleh (Priyono et al., 2011; Andriyanto et al., 2013):

Abnormalitas

$$
=\frac{\text { Jumlah larva abnormal }}{\text { Jumlah larva normal }} \times 100
$$

\section{Analisis Data}

Perbedaaan persentase abnormalitas dan daya tetas telur ikan bandeng dianalisis menggunakan One Way ANOVA. Apabila terdapat perbedaan maka dilanjutkan dengan uji Tukey.

\section{HASIL DAN PEMBAHASAN}

Hasil pengamatan selama penelitian terhadap larva ikan bandeng yang diberi ekstrak daun pepaya disajikan pada Tabel 1 . Daya tetas paling tinggi pada konsentrasi 4 ml sebesar 89,94 $\pm 1,61 \%$ sedangkan yang paling rendah pada konsentrasi $25 \mathrm{ml}$ sebesar $57,78 \pm 2,91 \%$. Hasil analisis One Way ANOVA menunjukkan terdapat perbedaan signifikan daya tetas telur ikan bandeng yang

Tabel 1. Daya Tetas Telur Ikan Bandeng yang diberi Ekstrak Daun Pepaya

\begin{tabular}{ccccccc}
\hline Ulangan & \multicolumn{6}{c}{ Perlakuan/Ekstrak Daun Pepaya (ml) } \\
& $\mathbf{2}$ & $\mathbf{4}$ & $\mathbf{6}$ & $\mathbf{1 0}$ & $\mathbf{2 0}$ & $\mathbf{2 5}$ \\
\hline 1 & 90,70 & 100 & 88 & 87,50 & 81,54 & 61,19 \\
2 & 90,77 & 84,73 & 88 & 75,38 & 72,73 & 57,25 \\
3 & 87,60 & 85,07 & 79 & 78,63 & 68,99 & 54,89 \\
Rerata \pm s.d & $89,69 \pm 1,81^{\text {a }}$ & $89,94 \pm 1,61^{\text {a }}$ & $84,78 \pm 6,64^{\text {a }}$ & $80,50 \pm 7,79^{\text {a }}$ & $74,42 \pm 8,72^{\text {a }}$ & $57,78 \pm 2,91^{\text {b }}$ \\
\hline
\end{tabular}

Keterangan: huruf superskrip yang sama pada baris yang sama menunjukkan tidak berbeda nyata $(\mathrm{P}>0,05)$

diberi ekstrak daun pepaya $(\mathrm{p}<0,05)$. Setelah dilakukan uji Tukey tidak terdapat perbedaan daya tetas pada konsentrasi 2, 4, 6, dan $20 \mathrm{ml}$ tetapi terdapat perbedaan daya tetas pada konsentrasi $25 \mathrm{ml}$.

Pada Tabel 2 menunjukkan konsentrasi yang paling tepat untuk 
mengurangi abnormalitas larva ikan bandeng pada konsentrasi $4 \mathrm{ml}$. Hasil analisis One Way ANOVA menunjukkan terdapat perbedaan signifikan abnormalitas larva ikan bandeng yang diberi perlakuan ekstrak daun pepaya $(p<0,05)$. Setelah dilakukan uji Tukey tidak terdapat perbedaan abnormalitas pada konsentrasi 2, 4, 6, dan $20 \mathrm{ml}$ tetapi terdapat perbedaan abnormalitas pada konsentrasi $25 \mathrm{ml}$.

Tabel 2. Abnormalitas Larva Ikan Bandeng yang diberi Ekstrak Daun Pepaya

\begin{tabular}{ccccccc}
\hline Ulangan & \multicolumn{6}{c}{ Perlakuan/Ekstrak Daun Pepaya (ml) } \\
\cline { 2 - 7 } & $\mathbf{2}$ & $\mathbf{4}$ & $\mathbf{6}$ & $\mathbf{1 0}$ & $\mathbf{2 0}$ & $\mathbf{2 5}$ \\
1 & 10,38 & 9,32 & 7,48 & 9,80 & 12,77 & 34,43 \\
2 & 13,46 & 5,71 & 10,78 & 13,95 & 20,00 & 56,25 \\
3 & 10,78 & 4,59 & 9,38 & 9,57 & 25,35 & 62,22 \\
Rerata \pm s.d & $11,54 \pm 1,68^{\mathrm{a}}$ & $6,54 \pm 2,47^{\mathrm{a}}$ & $9,21 \pm 1,66^{\mathrm{a}}$ & $11,11 \pm 2,46^{\mathrm{a}}$ & $19,37 \pm 6,32^{\mathrm{a}}$ & $50,97 \pm 14,63^{\mathrm{b}}$
\end{tabular}

Keterangan: huruf superskrip yang sama pada baris yang sama menunjukkan tidak berbeda nyata $(\mathrm{P}>0,05)$

Pada Tabel 2, terlihat jelas pada konsentrasi $25 \mathrm{ml}$ tingkat abnormalitas semakin meningkat menjadi 50,97 $\pm 14,63 \%$, sementara tingkat abnormalitas yang paling rendah ditemukan pada konsentrasi $4 \mathrm{ml}$ sebesar 6,54 $\pm 2,47 \%$. Pada konsentrasi $25 \mathrm{ml}$ terlihat tidak efektif dalam menurunkan persentase abnormalitas larva ikan bandeng. Sebagian besar larva abnormal terlihat pada pola mata yang rusak, kepala yang lebih kecil dari mata, dan tulang ekor yang lemah sehingga mudah patah.

Penurunan daya tetas telur yang disertai peningkatan abnormalitas larva pada konsentrasi $25 \mathrm{ml}$ diduga disebabkan oleh kandungan ekstrak daun pepaya yang jumlahnya dapat merusak jaringan pada telur dan larva ikan bandeng, sehingga larva yang tumbuh normal lebih sedikit jumlahnya.

Pemberian konsentrasi yang besar akan mengakibatkan kerusakan pada enzim sehingga kerja enzim penetasan terganggu yang dapat menghambat proses penetasan telur sehingga mengakibatkan abnormalitas pada larva ikan (Andriyanto et al., 2013; Redha et al., 2014; Murni et al., 2015; Ardhardiansyah et al., 2017). Lapisan terluar dari telur yang mengalami pengerasan menyebabkan embrio akan sulit untuk keluar, setelah lapisan terluar telur pecah maka embrio akan keluar dalam keadaan tubuh abnormal (Mukti et al., 2009). Embrio yang abnormal biasanya akan gagal menetas dan jika menetas kondisinya lemah dan akhirnya mati (Permana et al., 2016).

$$
\text { Konsentrasi terbaik untuk }
$$

meningkatkan daya tetas telur dan menurunkan persentase abnormalitas larva yaitu konsentrasi $4 \mathrm{ml}$. Hal ini, disebabkan oleh kandungan enzim proteolitik pada pepaya yang bekerja dengan baik sehingga memacu pertumbuhan embrio semakin cepat (Kusmini et al., 2012; Indra et al., 2014). Enzim proteolitik menyebabkan bertambah intensifnya penguraian glikoprotein lapisan lendir pada telur ikan. Penipisan lapisan lendir telur ikan diakibatkan oleh enzim proteolitik sehingga telur tidak tertempeli benda lain seperti kotoran yang dapat menghambat proses penetasan (Linhart et al., 2003). Enzim proteolitik sangat penting dalam membantu embrio lepas dari lapisan chorion selama proses penetasan (Fan et al., 2010) sehingga dapat mengurangi abnormalitas pada larva. 
Daun pepaya juga dapat menjadi anti jamur dan anti bakteri sehinggga menghambat proses pertumbuhan jamur dan bakteri penyebab abnormal pada larva ikan yang selanjutnya dapat meningkatkan daya tetas telur (Baskaran et al., 2012; Murni et al., 2015; Saptiani et al., 2016). Jamur yang sering menyerang larva biota air yaitu Lagenidium callinectes (Roza, 2012; Haryanto et al., 2015). Larva yang terinfeksi oleh jamur secara visual terlihat mengalami perubahan warna tubuh dari normal transparan menjadi keputih-putihan (Haryanto, 2008).

Menurut Walidin (2017), persentase daya tetas telur ikan bandeng tanpa ekstrak bahan alam sebesar 56 - 67,7\% sedangkan abnormalitas larva sebesar $36,2 \%$. Apabila mengacu pada penelitian tersebut maka dapat disimpulkan bahwa penggunaan ekstrak daun pepaya sangat efektif dalam meningkatkan daya tetas menjadi 89,94\% dan menurunkan persentase abnormalitas larva ikan bandeng menjadi 6,54\%. Penemuan konsentrasi ekstrak daun pepaya yang optimal diharapkan menjadi solusi bagi permasalahan budidaya ikan bandeng saat ini.

\section{KESIMPULAN}

Ekstrak daun pepaya dapat meningkatkan daya tetas telur ikan bandeng dan menurunkan persentase abnormalitas larva ikan bandeng. Konsentrasi yang tepat untuk meningkatkan daya tetas telur ikan bandeng dan menurunkan persentase abnormalitas larva ikan bandeng yaitu konsentrasi $4 \mathrm{ml}$.

\section{UCAPAN TERIMA KASIH}

Penulis mengucapkan banyak terima kasih kepada Direktorat Riset dan Pengabdian Masyarakat Direktorat Jenderal Penguatan Riset dan Pengembangan atas bantuan pembiayaan penelitian melalui skema penelitian dosen pemula.

\section{DAFTAR PUSTAKA}

Amri, E dan Mamboya, F. 2012. Papain, a Plant Enzyme of Biological Importance: A Review. American Journal of Biochemistry and Biotechnology. 8:(2): 99-104.

Andriyanto, W., Bejo, S., dan Ariawan, I.M.D.J.A. 2013. Perkembangan Embrio dan Rasio Penetasan Telur Ikan Kerapu Raja Sunu (Plectropoma laevis) pada Suhu Media berbeda. Jurnal Ilmu dan Telnologi Kelautan Tropis. 5(1): 192-203.

Andriyanto, S. 2013. Kondisi Terkini Budidaya Ikan Bandeng Di Kabupaten Pati, Jawa Tengah. Media Akuakultur. 8(2): 139-144.

Apines-Amar, M.J.S., Coloso, R.M., Jaspe, C.J., Salvilla, J.M., Amar-Murillo, M.N.G., dan Saclauso, C.A. 2015. Partial Replacement Of Soybean Meal With Fermented Copra Meal In Milkfish (Chanos chanos, Forsskal) Diet. AACL BIOFLUX. 8(6): 1019-1026.

Ardhardiansyah., Subhan, U., dan Yustiati, A. 2017. Embriogenesis Dan Karakteristik Larva Persilangan Ikan Patin Siam (Pangasius hypophthalmus) Jantan Dengan Ikan Baung (Hemibagrus nemurus) Betina. Jurnal Perikanan dan Kelautan. 8(2): 17-27.

Aslamyah, S., Karim, M.Y., Badraeni, dan Tahya, A.M. 2018. Effect Of Fermented Seaweed Addition On Blood Glucose Level, Hepatosomatic Index, And Gastric Evacuation Rate Of Milkfish, Chanos chanos Larvae. AACL BIOFLUX. 11(1): 226-231.

Azwar. 2017. Pengaruh Konsentrasi Ekstrak Daun Pepaya (Carica Papaya L.) Terhadap Penetasan Telur Ikan Bandeng (Chanos Chanos Forskall). Skripsi. Program Studi 
Perairan. Universitas Almuslim. Aceh.

Baskaran, C., Ratha bai, V., Velu, S., Kumaran, K. 2012. The Efficacy Of Carica papaya Leaf Extract On Some Bacterial And A Fungal Strain By Well Diffusion Method. Asian Pacific Journal of Tropical Disease. S658-S662.

Budiasti, R.R., Anggoro, S., dan Djuwito. 2015. Beban Kerja Osmotik dan Sifat Pertumbuhan Ikan Bandeng (Chanos chanos Forskal) Yang Dibudidaya Pada Tambak Tradisional di Desa Morosari dan Desa Tambakbulusan Kabupaten Demak. Diponegoro Journal Of Maquares. 4(1): 169-176.

Fan, T., Wang, J., Yuan, W., Zhong, Q., Shi, Y., dan Cong, R. 2010. Purification And Characterization Of Hatching Enzyme From Brine Shrimp Artemia Salina. Acta Biochimica Et Biophysica Sinica. 42(2): 165-171.

Haryani, A., Grandiosa, R., Buwono, I.D., dan Santika, A. 2012. Uji Efektifitas Daun Pepaya (Carica papaya) Untuk Pengobatan Infeksi Bakteri Aeromonas hydrophila Pada Ikan Mas Koki (Carasius auratus). Jurnal Perikanan dan Kelautan. 3(3): 213-220.

Haryanto, S. 2008. Isolasi Jamur Lagenidiales Pada Larva Kepiting Bakau (Scylla tranquebarica). Bul. Tek. Lit. Akuakultur. 7(1):5358.

Haryanto, S., Suratmi, S., dan Ansari, M. 2015. Teknik Isolasi Penyakit Infeksi Jamur Pada Larva Kuda Laut, Hippocampus kuda di Hatcheri dan Upaya Pengendaliannya. Tek. Lit. Akuakultur. 13(1): 73-77.

Hikmayani, Y., dan Putri, H.M. 2014. Strategi Pengembangan Pasar Bandeng (Chanos chanos sp). J. Kebijakan Sosek KP. 4(1): 93-104.
Indra, I.S.S., Rachimi., dan Raharjo, E.I. 2014. Pengaruh Getah Pepaya (Carica papaya L.) Kering Terhadap Derajat Pembuahan Dan Penetasan Telur Ikan Jambal Siam (Pangasius hypothalamus). Jurnal Ruaya. 2: 29-38.

Jaspe, C.J. dan Caipang, C...M.A. 2011. Nursery Production Of HatcheryReared Milkfish, Chanos chanos In Earthen Ponds. AACL BIOFLUX. 4(5): 627-634.

Kusmiati. 2012. Kemampuan Senyawa Lutein dari Daun Bayam (Amaranthus sp) untuk Menetralisir Oksidan T-BHP dalam Sel Darah. Seminar Nasional IX Pendidikan Biologi FKIP UNS. 691-695.

Kusmini, I.I., Faqih, I.S., dan Huwoyon, G.H. 2012. Perbedaan Suhu Terhadap Kecepatan Perkembangan Embriogenesis Ikan Tengadak (Barbonymus schwanenfeldii). Prosiding Indoaqua - Forum Inovasi Teknologi Akuakultur. 1189-1195.

Kusumawati, D., Jamaris, Z., Aslianti, T. 2017. Profil Pertumbuhan, Enzimatis, dan Nutrisi Ikan Bandeng (Chanos chanos) Generasi Kedua (G-2) Terseleksi Dengan Menerapkan Standar Operasional Prosedur (SOP) Pemeliharaan Larva. Media Akuakultur. 12(2): 55-66.

Langaoen, A.F., Manzano, V.J.V., Requilman, E.M.R., Tabardillo, J.M. Maningas, M.B.B., dan Calugay, R.J. 2018. AntibioticResistant Bioluminescent Vibrios From Philippine Aquacultured Chanos chanos and Oreochromis niloticus. AACL BIOFLUX. 11(2): 505-515.

Linhart, O., Gela, D., Flajshans, M., dan Rodina, M. 2003. Proteolytic Enzyme Treatment: An Improved Method For Elimination Of Egg Stickiness In Tench, Tinca tinca 
L., In Aquaculture. J. Appl. Ichthyol. 19: 134-137.

Malik, A. 2010. Pengaruh Pemberian Suplemen Dan Probiotik Terhadap Hasil Panen Bandeng (Chanos chanos) Di Wilayah Desa Kentong Kecamatan Glagah Kabupaten Lamongan. 1(1): 57-65.

Mardjono, M., Soni, A.F.M., dan Sutikno, E. 2013. Penggunaan Pakan Buatan Yang Diperkaya Ekstrak Pepaya Pada Pendederan Benih Kerapu Macan (Epinephelus fuscogutattus). Prosiding Forum Inovasi Teknologi Akuakultur. 465-469.

Martuti, N.K.T., Widianarko, B., Yulianto, B. 2016. The Pattern Of $\mathrm{Cu}$ Accumulation In Milkfish (Chanos chanos) During Growth Period In Fishpond In Dukuh Tapak Tugurejo Semarang, Indonesia. AACL BIOFLUX. 9(5): 1036-1043.

Monica, M., Wardiyanto, Susanti, O. 2017. Kajian Potensi Ekstrak Daun Pepaya (Carica papaya 1) Terhadap Immunitas Non Spesifik Udang Vaname (Litopenaeus vannamei). Jurnal Ilmiah Perikanan dan Kelautan. 9(2): 127133.

Mukti, A.T., Arsianingtyas, H., dan Subekti, S. 2009. Pengaruh Kejutan Suhu Panas dan Lama Waktu Setelah Pembuahan Terhadap Daya Tetas dan Abnormalitas Larva Ikan Nila (Oreochromis niloticus). Jurnal Ilmiah Perikanan dan Kelautan. 1(2): 163-168.

Nwofia, G.E., dan Ojimewlukwe, P. 2012. Variability and Proximate, Mineral and Vitamin Contents of Carica papaya (L) Leaves, Fruit Pulp and Seeds. Int. J. Med. Arom. Plant. 2(1): 90-96.

Nwofia, G.E., Ojimewlukwe, P., dan Eji, C. 2012. Chemical Composition of Leaves, Fruit Pulp and Seeds in Some Carica papaya
Morphotypes. Int. J. Med. Arom. Plant. 2(1): 200-206.

Pandey, S., Cabot, P.J., Shaw, P.N., dan Hewavitharana, A.K. 2016. Antiinflammatory and immunomodulatory properties of Carica papaya. Journal of Immunotoxicology. 1-13.

Permana, A., Musthofa, S.Z., Murniasih, S., Priyadi, A., Nur, B. 2016. Optimalisasi Teknik Inkubasi Telur Ikan (Agamyxis sp.) Dengan Perlakuan Suhu Berbeda. Prosiding Forum Inovasi Teknologi Akuakultur. 393-397.

Priyono, A., Aslianti, T., Setiadharma, T., dan Giri, I.N.A. 2011. Petunjuk Teknis Perbenihan Ikan Bandeng (Chanos chanos Forsskal). Balai Besar Penelitian dan Pengembangan Budidaya Laut. Badan Penelitian dan Pengembangan Kelautan dan Perikanan. KKP. Jakarta. $45 \mathrm{hlm}$.

Ratnawati, E., Mustafa, A., dan Anugriati. 2010. Faktor Pengelolaan Yang Mempengaruhi Produksi Ikan Bandeng (Chanos chanos) Di Tambak Kabupaten Bone, Provinsi Sulawesi Selatan. Prosiding Forum Inovasi Teknologi Akuakultur. 151-159.

Redha, A.R., Raharjo, E.I., dan Hasan, H. 2014. Pengaruh Suhu Yang Berbeda Terhadap Perkembangan Embrio dan Daya Tetas Telur Ikan Kelabau

(Osteochilus melanopleura). Jurnal Ruaya. 4: 18.

Roza, D. 2012. Kematian Massal Larva Udang Windu, Penaeus monodon Fabricius Akibat Infeksi Lagenidium callinectes. Prosiding Indoaqua - Forum Inovasi Teknologi Akuakultur. 691-697.

Saptiani, G., Hardi, E.H., Pebrianto, C.A., dan Agustina. 2016. Ekstrak Daun Pepaya dan Kangkung untuk Meningkatkan Daya Tetas Telur dan Kelangsungan Hidup Larva 
Lele. Jurnal Veteriner. 17(2): 285291.

Sembiring, S.B.M., Wibawa, G.S. Setiadharma, T., dan Haryanti. 2017. Pertumbuhan Dan Variasi Genetik Ikan Bandeng, Chanos chanos Dari Provinsi Aceh, Bali, dan Gorontalo, Indonesia. Jurnal Riset Akuakultur. 12(4): 307-314.

Tumilba, V., dan Yarime, M. 2015. Ecological Network Metrics In Assessing Sustainability Of The Philippine Milkfish (Chanos chanos) Economic Resource System. AACL BIOFLUX. 8(3): 253-264.

Tutas, L.B., Serrano Jr, A.E., Traifalgar, R.F.M., dan Corre, V.L. 2013. Optimum Dietary Levels Of Vitamin A (Retinyl Palmitate) For Growth And Reduction Of Incidence Of Operculum Deformity In Milkfish (Chanos chanos) fry. AACL BIOFLUX. 6(5): 464-469.

Virgula, J.C., Cruz-Lacierda, E.R., Estante, E.G., dan Corre Jr, V.L. 2017. Copper Sulfate As Treatment For The Ectoparasite Amyloodinium Ocellatum (Dinoflagellida) On Milkfish (Chanos chanos) fry. AACL BIOFLUX. 10(2): 365371.

Walidin, M. 2017. Efektivitas Ekstrak Daun Nenas (Ananas cosmosus) Terhadap Penetasan Telur Ikan Bandeng (Chanos chanos Forskall). Skripsi. Program Studi Perairan. Universitas Almuslim. Aceh.

Zamroni, A., Mulyawan, I., dan Priyatna, F.N. 2015. Potensi Ekspor Nener Bandeng Indonesia: Peluang Dan Tantangan. J. Kebijakan Sosek KP. 5(2): 129-136. 